\title{
Needs Analysis on the Importance of English Communication Skills for Government Officials in Myanmar
}

\author{
Omar Lin, Nalini Arumugam, Faizah Mohamad, Puspalata C Suppiah, Aung \\ Soe Lwin
}

To Link this Article: http://dx.doi.org/10.6007/IJARBSS/v11-i3/8975

DOI:10.6007/IJARBSS/v11-i3/8975

Received: 01 February 2021, Revised: 28 February 2021, Accepted: 10 March 2021

Published Online: 18 March 2021

In-Text Citation: (Lin et al., 2021)

To Cite this Article: Lin, O., Arumugam, N., Mohamad, F., Suppiah, P. C., \& Lwin, A. S. (2021). Needs Analysis on the Importance of English Communication Skills for Government Officials in Myanmar. International Journal of Academic Research in Business and Social Sciences, 11(3), 612-624.

\section{Copyright: @ 2021 The Author(s)}

Published by Human Resource Management Academic Research Society (www.hrmars.com)

This article is published under the Creative Commons Attribution (CC BY 4.0) license. Anyone may reproduce, distribute, translate and create derivative works of this article (for both commercial and non-commercial purposes), subject to full attribution to the original publication and authors. The full terms of this license may be seen at: http://creativecommons.org/licences/by/4.0/legalcode

Vol. 11, No. 3, 2021, Pg. 612 - 624

Full Terms \& Conditions of access and use can be found at http://hrmars.com/index.php/pages/detail/publication-ethics 


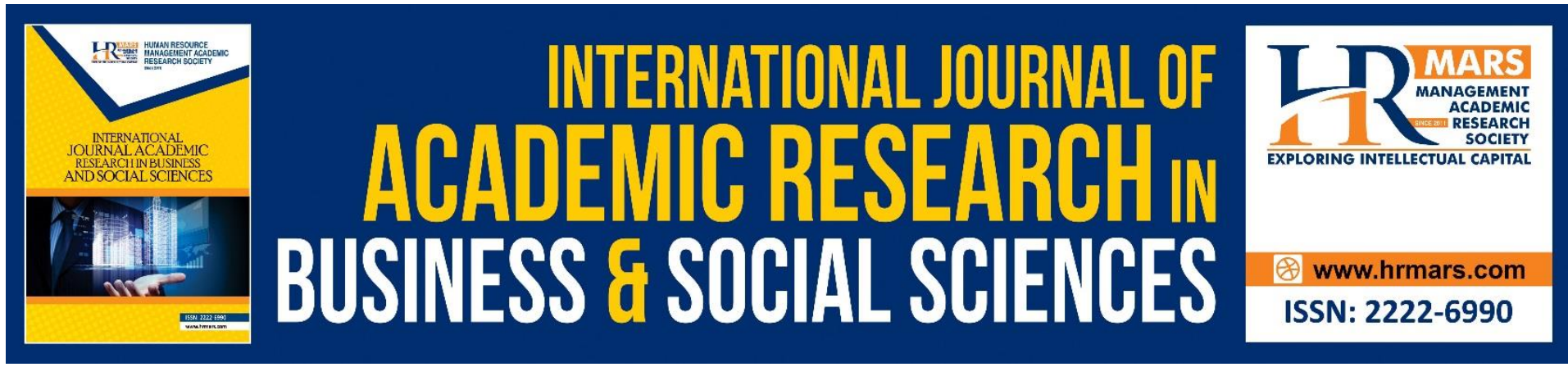

\title{
Needs Analysis on the Importance of English Communication Skills for Government Officials in Myanmar
}

\author{
Omar Lin, Nalini Arumugam, Faizah Mohamad, Puspalata C \\ Suppiah, Aung Soe Lwin \\ ${ }^{1}$ Ministry of Investment and Foreign Economics Relations, Myanmar, ${ }^{2,3}$ \& 4 Akademi
} Pengajian Bahasa, Universiti Teknologi MARA, Shah Alam, ${ }^{5}$ Myanmar Institute of Education,

Myanmar

Email: nalini@uitm.edu.my

\section{Abstratct}

Government officials in Myanmar are the official gatekeepers in the country. This study was carried out to examine the communication needs of government officials so as to address this gap. A quantitative methodology was adopted to gauge the language skills needed at the workplace. 99 government officials from the Ministry of Investment and Foreign Economic participated in this study. The results signaled that the government officials had a high level of needs in learning English language with the mean value of $4.41(S D=.535)$. The result also indicated a dire need of mastery in the English language $(M=4.48, S D=.522)$. The higher ranked government officials shared that they needed English language skills to communicate effectively with the mean value of $4.37,(S D=.679)$ while the lower ranked officials $(M=4.33$, $\mathrm{SD}=.655$ ) to enable government officials to understand and communicate with foreign investors. In conclusion, the results anchored that English language is essential for government officials to execute their duties and responsibilities regardless of their ranks. Recommendations for ESP course-design are further discussed.

Keywords: Government Officials, English Language Skills, Workplace, ESP Course

\section{Introduction}

Myanmar is in the process of transformation. It has opened up to international diplomatic relationships economically and politically, and is inviting international investments. Myanmar government officials are relating and communicating with visitors from international government agencies, companies and investors every day (Cho Mar, 2020). This is a major issue in Myanmar as many Myanmar government officials are not well versed in terms of English communicative skills (Takashi, 2014). Good mastery in English language leads to personal career development for the officials (MOE, 2013, UNICEF Myanmar, 2013). However, it is crucial that government officials realise that proficiency in the English language is important not only for their career development but also in executing their responsibilities effectively. In fact, English proficiency is a vital factor for their career development as well as government work, which contributes to national development (Chao, 2018). 
English has been taught in Myanmar as a foreign language throughout different education systems under the Myanmar government since its independence from the British rule. However, recently, it is well observed that the English skills of people in Myanmar, especially government officials, seem to decline while Burmese has become the official language used in government offices. The new government is opening up the doors to international communities in which the Myanmar government officials are expected to communicate with the international communities in English. Since Myanmar government officials lack good English language skills, they have difficulties and problems in having effective communication and maintaining good relationship with international communities.

In an attempt to enhance the performance skills among government officials, the Myanmar government has been conducting English language enhancement programs such as workshop, seminar and training through government agencies. Efforts of human resources and financial aspects have been invested for the training and developing English language among government officials. While there have been reforms in government agencies in improving the English skills of government officials, it is also very important to understand the perspectives of different stakeholders in government works on the opportunities, potentials, challenges and problems in pursuing English language improvement (MOE, 2013; Salmi, 2013). It is indisputable that English is the most extensively used language and has become the language of diplomacy and international relations based on the economic and political status of the country they had in the globe (Gjata, 2017).

Koksal and Ulum (2016) studied the need of English language for the Turkish public order police officers and proposed that a special course should be introduced to all police officers who work or will work in tourist places based on their perceived needs. Needs Analysis (NA) relates to the characteristics, concerns and potential constraints of the participants. The analysis seeks to match possible techniques and identify whether the design is appropriate to the intended goals. Additionally, need analysis means a plan for gathering information to make decisions about priorities and a method to know the difference between the desired conditions with the existing conditions. The desired conditions are often referred to as ideal conditions. NA is an information gathering process. Its emergence in language planning can be traced back to the 1970 s and its wide spread proliferation in the domain attributed to its adoption by the NA is considered as a basic principle of ESP (Robinson, 1991).

Elyas and Algofaili (2019) pointed out that in Saudi, the officers who graduated from the King Abdulaziz Military Academy were incompetent and they struggled communicating in English with others. This encouraged them to take English courses after their graduation. They realised that teachers do not have well-planned ESP training courses and they may not be familiar teaching English and lack knowledge in this field. Hashmi, Rajab, and Sindi, (2020) pointed out that learners had a very positive attitude towards learning of the English language and they were aware of their contextual constraints; therefore, it is significant to consider their 'wants' while designing an English language course for dental students.

Existing materials have to be complemented with added appropriate topics and language functions applicable to the local government officials in Myanmar. Not only do government officials have to learn how to express the important language topics and functions, they also need lessons on how to use the correct language style, to use it in the right contexts, 
distinguish levels of formality as it relates to gender, social status, and setting (Schachter, 2013). It is noteworthy that English language education has taken a new phase where it is recognised as an essential tool for continued growth and expansion within all dimensions of Myanmar (Soe, 2015; UNESCO, 2010). Erling (2017) pointed out that the English language skills are extensively remunerated in corporate world as competency in this language has a constructive impact on economic growth. Therefore, it is essential to investigate the perceived needs in the English language competence and communicative needs of Myanmar government officials as they often represent the country in economy and political arena.

\section{Statement of the Problem}

A broad overview of the health sector in Myanmar reveals that English is the primary lingua franca in the public administration. A large percentage of the correspondence in the medical sector is done in English. A weak grasp in the English language skills curtails effectual communication, causes misinterpretation at times and also creates impediment among the employees (Arumugam \& Kaur, 2011; Miina, 2014). English language is used commonly and competence in the language has become a crucial skill in securing an employment in the corporate world. Proficiency in the language means not merely the ability to make grammatically correct sentences but also to equip oneself with workplace related skills like presentation skills, convincing and negotiation skills and interpersonal skills using the right choice of words in English (Arumugam, Munchar, Bala Subramaniam, \& Selvanayagam, 2020; Clement \& Murugavel, 2018). They also pointed out that the necessitate of being proficient in the English language likely due to the global market. The requirements of English language are likely to go on an upward trend and those who are not competent in English language skills may face challenges to climb the ladder professionally.

Myanmar government officials are relating and communicating with visitors from international government agencies, companies and investors every day (Cho Mar, 2020). This is a major concern in Myanmar as many Myanmar government officials are not competent in their English communicative skills (Takashi, 2014). Good mastery in English language leads to personal career development for the officials (MOE, 2013, UNICEF Myanmar, 2013). However, it is crucial that government officials realise that proficiency in the English language is important not only for their career development but also in executing their responsibilities effectively. In fact, English proficiency is a vital factor for their career development as well as government work, which contributes to national development (Chao, 2018).

Oktarin, Syahrial, and Harahap (2019) advocated that English teachers should provide materials for the tourism students by using authentic materials related to tourism to fulfil learners' needs. This will also guide the students to explore their English skills in order to be more confident in their career upon completion of their studies. Lin and Huang (2014) and said that it is significant to have special English course for the Taiwanese government officials, hotel industries, educational institutes, students, and other jobs which may benefit from hospitality students and hotel industries.

It is advocated by researchers (Ireland \& Benthuysen, 2014; Neeley, 2012; Wong, 2005) that English language proficiency plays an important role for career as well as national development and to help leaders play their roles commendably. 
As a result, improving English language proficiency among government officials in Myanmar is a pressing need. In Myanmar, within the limits of the researchers' knowledge, few studies have addressed the government officials' needs of English communication skills and the problems they confront during their official duties and when communicating with public or representatives from foreign countries. Therefore, this study aims to investigate the English language communication needs of government officials in Myanmar to further understand the situation.

\section{Research Questions}

The present study is based on Hutchinson and Waters (1987) and Dudley-Evans and St John (1998) needs analysis framework. The focus of this study is an analysis of the target needs of government officials in Myanmar at the workplace. This research attempted to answer the following questions.

RQ 1: What are the needs of government officials in learning English language?

RQ 2: What are the needs of government officials to learn English as a means of communication in the workplace?

RQ 3: What are the English language needs of the high-ranked Government officials in the workplace?

RQ 4: What are the English language needs of the low-ranked Government officials in the workplace?

\section{Methodology}

In this study, a survey research methodology was employed to achieve the research objectives. A set of questionnaire was adopted from Arumugam and Kaur (2011) to elicit information from sample population of 100 Myanmar government officials from the Ministry of Investment and Foreign Economic. However, one respondent's questionnaire was incomplete, therefore only 99 complete responses were analysed which comprised 64 female and 35 male respondents respectively. The questionnaire was divided into three sections: Section A deals with demographic and academic qualification and Section B elicits information related to knowledge of languages pertaining to their occupation. Meanwhile, Section $C$ draws on the respondents' perceptions of the need for English language to execute their official duties at workplace. Data collected were analysed using SPSS and descriptive statistics were gathered to see the levels of English language needs of government officials in Myanmar. The majority of the respondents, $42 \%$ fall into the category of ages 30 to 39 years old followed by $29 \%$ between the age range of 40 and 49 and 21 to 29 old respectively. Only $7 \%$ of the respondents fall under the 50 years and above age category.

\section{Results and Discussions}

The section will look at the level of English language needs of the government officials in Myanmar after the data gathered from the questionnaire were analysed. The findings are presented using the descriptive statistics based on the research questions of the study.

RQ 1: What are the needs of government officials in learning English language?

When the government officials were asked to rate their need for English language, the mean value for most of the descriptions were rated more than 4.00 as indicated in Table 1. 
Table 1 shows that the government officials in Myanmar had a high level of needs in learning English language as the mean values were above 3.5 in a 5-point Likert scale type of responses. The values of standard deviation were low, thus these indicated that the data were clustered closely around the means and not widely spread (more reliable). Based on the means, the highest level of needs to learn English was to use English in their future environment ( $M=4.41, S D=.535)$. This was followed by reporting of the importance of English for government officials $(M=4.30, S D=.735)$. Then, the needs of learning English was seen in providing opportunities to exposure in giving effective training $(M=4.26, S D=.632)$. Next, they also seemed to have the needs to learn English when they had to present in English in the workplace ( $M=4.19, S D=.695)$. Focusing on practice in language skills more related to officials' specialised areas of study and identifying the needs of effective specialized ways of course contents in relation to the workplace had the same level of needs $(M=4.16)$ with the $S D=.601$ and $S D=.618$ respectively. The government officials also perceived that they needed to learn English due to the issues of their English skills ( $M=4.05, S D=.629)$. Emphasizing writing and speaking skills than other two skills had the mean level of need at 3.97 ( $S D=.886$ ) and finally they felt that they needed to learn English as they had problems in using English in the work place $(\mathrm{M}=3.83, \mathrm{SD}=.770)$.

Table 1: Perceived needs of government officials in learning English language

\begin{tabular}{|l|l|l|l|}
\hline Descriptive Statistics & N & Mean & $\begin{array}{l}\text { Std. } \\
\text { Deviation }\end{array}$ \\
\hline $\begin{array}{l}\text { Expressing the needs of English Learning of government } \\
\text { officials in their future environments }\end{array}$ & 99 & 4.41 & .535 \\
\hline Reporting the importance of English for government officials & 99 & 4.30 & .735 \\
\hline $\begin{array}{l}\text { Providing opportunities to exposure in giving effective training } \\
\text { Presenting English skills they needs in their workplace }\end{array}$ & 99 & 4.26 & .632 \\
\hline $\begin{array}{l}\text { language } \\
\text { officials' specialized areas of study }\end{array}$ & 99 & 4.16 & .695 \\
\hline $\begin{array}{l}\text { Identifying the needs of effective specialized ways of course } \\
\text { contents in relation to the workplace }\end{array}$ & 99 & 4.16 & .601 \\
\hline Stating issues of the government officials' English skills & 99 & 4.05 & .629 \\
\hline $\begin{array}{l}\text { Emphasizing writing and speaking skills than other two skills } \\
\text { Stating problems facing in the use of English in the workplace }\end{array}$ & 99 & 3.97 & .886 \\
\hline Valid N (listwise) & 99 & 3.83 & .770 \\
\hline
\end{tabular}

RQ 2: What are the needs of government officials to learn English as a means of communication in the workplace?

This section presents the government officials' priorities to learn English as a mode of interaction hence, they were asked to select the needs provided in Table 2. 
Table 2: Perceived needs of government officials to learn English as a means of communication in the workplace.

\begin{tabular}{|l|l|l|l|}
\hline Descriptive Statistics & N & Mean & $\begin{array}{l}\text { Std. } \\
\text { Deviation }\end{array}$ \\
\hline $\begin{array}{l}\text { Able to understand and communicate with foreigners in } \\
\text { English language }\end{array}$ & 99 & 4.48 & .522 \\
\hline $\begin{array}{l}\text { Able to discuss or negotiate with the related matters during } \\
\text { the meetings such as forums, seminars, workshop, etc }\end{array}$ & 99 & 4.22 & .632 \\
\hline $\begin{array}{l}\text { Able to replay formal letters in English sent from foreign } \\
\text { countries, internal and external }\end{array}$ & 99 & 4.21 & .674 \\
\hline $\begin{array}{l}\text { Able to improve translation skill to avoid any } \\
\text { misunderstanding }\end{array}$ & 99 & 4.21 & .627 \\
\hline $\begin{array}{l}\text { Able to develop the learning courses needed to improve } \\
\text { English Communication }\end{array}$ & 99 & 4.20 & .654 \\
\hline $\begin{array}{l}\text { Able to overcome for the difficulty with speaking skill being } \\
\text { due to the face to face nature of the communication }\end{array}$ & 99 & 4.19 & .617 \\
\hline $\begin{array}{l}\text { Able to write formal letters such as Business letters } \\
\text { Able to use the terms of the functions of English language in } \\
\text { their work place }\end{array}$ & 99 & 4.13 & .600 \\
\hline Valid N (listwise) & 99 & & .600 \\
\hline
\end{tabular}

In terms of the needs in learning English as a means of communication, it was discovered that the government officials also had a high level of needs as the mean values were above 4.0 in a 5-point Likert scale type of responses as illustrated in Table 2. The values of standard deviation were low, thus these indicated that the data were clustered closely around the means and not widely spread (more reliable). The government officials perceived that they needed to learn English the most in order to understand and communicate with foreigners in English language ( $M=4.48, S D=.522)$. Next, learning English was also needed so that they were able to discuss or negotiate with the related matters during the meetings such as forums, seminars, workshop, etc ( $M=4.22, S D=.632)$. This was followed by being able to replay formal letters in English sent from foreign countries, internal and external and improve translation skill to avoid any misunderstanding which had the same mean value $(M=4.21)$ with $S D=.674$ and $\mathrm{SD}=.627$ respectively. Then, English was needed to be learnt in order to develop the learning courses for English communication improvement $(M=4.20, S D=.654)$. Next, the government officials needed to learn English to overcome the difficulty in speaking face to face as the nature of the communication $(M=4.19, S D=.617)$. The final two reasons which had the same mean and SD ( $M=4.13, S D=.600)$ were being able to write formal letters such as business letters and to use the terms of the functions of English language in their work place.

RQ 3: What are the English language needs of the high-ranked government officials in the workplace?

The government officials in high-rank positions were asked to choose their reasons for learning the English language. The statistical findings were illustrated in Table 3. 
Table 3: The English language needs of the high-ranked government officials in the workplace

\begin{tabular}{|c|c|c|c|}
\hline \multicolumn{4}{|l|}{ Descriptive Statistics } \\
\hline & $\mathrm{N}$ & Mean & $\begin{array}{c}\text { Std. } \\
\text { Deviation }\end{array}$ \\
\hline Officials will be able to deal with foreigners effectively & 99 & 4.37 & .679 \\
\hline $\begin{array}{l}\text { It will enhance Capacity building of the needs of } \\
\text { workplace within the relevant organizations }\end{array}$ & 99 & 4.22 & .663 \\
\hline $\begin{array}{l}\text { It will more improve organizational development in } \\
\text { workplace }\end{array}$ & 99 & 4.15 & .747 \\
\hline It will help to write business letters & 99 & 4.13 & .617 \\
\hline $\begin{array}{l}\text { It is needed to be effective in the areas of managerial } \\
\text { level of officials concerned }\end{array}$ & 99 & 4.04 & .713 \\
\hline Valid N (listwise) & 99 & & \\
\hline
\end{tabular}

Table 3 shows that the English language needs of the high-ranked government officials were high as the mean values were above 4.0 in a 5-point Likert scale type of responses. The values of standard deviation were low, thus these indicated that the data were clustered closely around the means and not widely spread (more reliable). The results revealed that highranked Government officials needed English language most when they were to deal with foreigners effectively ( $M=4.37, S D=.679)$. This was followed by enhancing capacity building of the needs of workplace within the relevant organisations $(M=4.22, S D=.663)$ and improving organisational development in workplace $(M=4.15, S D=.747)$. Next, they perceived that they needed English language to help them write business letters $(M=4.13, S D=.617)$ and finally, to be effective in the areas of their managerial level $(M=4.04, S D=.713)$.

RQ 4: What are the English language needs of the low-ranked government officials in the workplace?

In this section, the low-ranked government officials have stated their needs to acquire the English language. The findings were presented in Table 4.

Table 4: The English language needs of the low-ranked government officials in the workplace

\begin{tabular}{|l|r|r|r|}
\hline \multicolumn{3}{|c|}{ Descriptive Statistics } & \multicolumn{1}{|c|}{ N } \\
\hline
\end{tabular}

Table 4 shows that the English language needs of the low-ranked government officials were high as the mean values were also above 4.0 in a 5 point Likert scale type of responses. The 
values of standard deviation were low, thus these indicated that the data were clustered closely around the means and not widely spread (more reliable). The result revealed that the low-ranked government officials needed English language most when they were to deal with foreigners effectively $(M=4.33, S D=.655)$. This was followed by improving organisational development in workplace and helping them to write business letters which had the same mean value $(M=4.16)$ with $S D=.681$ and $S D=.566$ respectively. Next, the final two reasons why they needed English language were to be effective in the areas of their managerial level and to enhance capacity building of the needs of workplace within the relevant organizations which also had the same mean value (4.11) with $\mathrm{SD}=.621$ and $S D=.587$ respectively.

\section{Discussion}

The findings showed that the government officials in Myanmar agreed that the mastery of the English language is highly needed within their job scope to function competently in their job. Clement and Murugavel (2018) asserted that the knowledge of English in corporate communication has become one of the most important employability skills. Realising this, the officials indicated the necessity of learning the language to deliver effective in-house or workbased trainings. This finding is parallel with Durga's claim (2018. p. 2) which stated that "employers started conducting English training programmes for their employees in order to reach the target in their business". Another striking finding is that, speaking and writing have been considered the most sought-after skills by the officials compared to reading and listening. This, perhaps can be explained by the fact that the government officials need to be proficient in English to communicate with those within their organisation as well as the public regarding official matters. This finding is in accordance with Saleh and Murtaza's (2018) research findings which stressed that the ability to speak in English was most demanded skill in the workplace. The findings of Kaewpet (2009), however, is not in tandem with the findings of Saleh and Murtaza (2018) which emphasised the reading and writing skills as more important than other language skills within Thailand's engineering sector. So, depending on the needs of different sectors, different language skills are given priority.

In Myanmar, although English is only taught as a popular foreign language, the government officials realise the importance of learning English due to the nature of their work which requires them to deal and communicate especially with foreign stakeholders. The language is further needed when discussing or negotiating official matters during forums, seminars, and workshop. Ting, et al. (2017) affirm that a "good mastery of English is exceedingly important for jobs involving customer service, frontline service and marketing, and in globallypositioned companies" (p. 325). In view of this, Pattanaoichet and Chinokul (2011) indicated that most future employers in the public relations sector in Thailand prefer not to recruit local university graduates who lacked confidence communicating in English. Besides mastering the language for communication purpose, the Myanmar officials said that having a good command of the English language can prevent them from any kind of misunderstanding be it spoken or written. The misunderstandings, however are more prevalent among speakers who do not share a native language, than between native speakers of the same language (Mauranen, 2006).

It is evident from the findings that English has a strong demand among the government officials in Myanmar due to its relevance around the world. Officials in the high rank position have shown keen interest in learning the English language mainly to facilitate capacity 
building initiatives in their organisation. They believe that the organisational development in workplace can be improved if the officials are fluent in English. One can imagine the impact caused by those with poor English skills while making crucial decisions in an organisation. Certainly, having a good competency of the English language is crucial in today's corporate world, not only for effective communication but to increase the organisation's productivity. Having recognised the need for good English, organisations nowadays employ "people who can interact successfully and make significant contributions during group-discussions, presentations and seminars (Pandey \& Pandey, 2014, p. 98).

The English language needs of the low-ranked government officials is similar to that of the high-ranked officials in the Myanmar government sector. Both groups of officials regardless of their ranks, have shown keen interest in learning the language mainly to enable them to deal effectively with foreign clienteles. Another important finding is that, unlike the officers in the high-rank position who see the need of mastering the English language for organisational development and capacity building, officials at the lower rank needed the language to perform well in the areas of managerial level. This is consistent with Clement and Murugavel's study (2018) which established that corporate employees emphasised the necessity for in-house English training for improvement of skills required to execute their duties. Hence, effective and efficient course designs and contents are necessary to be developed to suit their working environment.

\section{Conclusion}

To conclude, this study is carried out to provide an insight into the English language needs of the Myanmar government officials for various reasons. It is generally known that English is learnt in Myanmar as a foreign language yet, the language is presently gaining importance among the officials at the government sector specifically to communicate with foreigners, for internal organizational development and work-related purposes. As such, these officials see the need of acquiring the spoken and written skills more than reading and listening skills to function competently in their routine works. Although the present investigation does not include all government officials throughout the nation, the researchers believe that the sample used in this study is relatively sufficient in representing the population. The salient findings from this study can be used as guidelines for designing modules and syllabus for employees working in different employment sectors in Myanmar. Hence, course designers should take into consideration of all the four language skills although findings of this study revealed that speaking and writing skills are highly valued. Any proposed modules and materials should integrate all the four skills in an effective way to help employees develop their competence in the English language. The four language skills - listening, speaking, reading and writing, do not function independently but integrating them will produce a complete well-rounded listeners, speakers, readers and writers (Sadiku, 2015).

\section{Pedagogical Implications}

Since the study focuses on the needs of English communication skills among government officials in Myanmar, it will help the Myanmar government to understand the importance of English language skills for the government officials in completing their tasks effectively and efficiently. In addition, it also gives an insight on which language skills should be focused on and how a series of good training can be planned for the Myanmar government officials. With 
this understanding, it is hoped that the officials are given sufficient English language training which are relevant to the needs and nature of the job.

The results of this study highlight the importance of considering the absolute skills and variable characteristics in developing English for Specific Purposes for not only government officials in Myanmar but also all adult or professional learners as to prepare them to assume as well as to carryout their roles effectively at their workplace as suggested by Dudley-Evans and St John (1998). The responses of the participants indicate that the existing curriculum for the English language is not sufficient to meet their needs because their workplace requirement needs practical input for them to perform well. An implication of this for curriculum designers is the need to find and adapt appropriate materials, focusing on the linguistic skills requirement in the workplace that cater to the needs of these officials so that they will undergo the training that can help them improve their English language proficiency. In order to ensure the effectiveness of the training, feedback and development sessions should be conducted after the training for future improvement.

\section{References}

Arumugam, N., \& Kaur, N. (2011). Needs analysis on the importance of English communication skills for medical assistants. Journal of Institutional Research South East Asia, 9(1), May/June 2011- ISSN 1675-6061

Arumugam, N., Munchar, J., Bala Subramaniam, A. L. \& Selvanayagam. (2020). Figure it out: Creative language expressions in ESL writing classroom. Universal Journal of Educational Research, 9(8), 4187-4192. ISSN: 2332-3213 (Online). URL: http://www.hrpub.org/journals/jour_archive.php?id=95.

Mar, M. T. C. (2020). Myanmar Youth and Impact of English Language Proficiency Towards Job Grabbing. In International Conference on Community Development (ICCD 2020) (pp. 416-420). Atlantis Press.

Chao, R. Y. (2018). Higher education systems and institutions, Myanmar. In: Teixeira P., Shin J. (eds) Encyclopedia of international higher education systems and institutions. Springer, Dordrecht. https://doi.org/10.1007/978-94-017-9553-1_511-1

Clement, A., \& Murugavel, T. (2018). English for the workplace: The importance of English language skills for effective performance. The English Classroom, 20(1), 1-15.

Dudley-Evans, T., \& St John, M. J. (1998). Developments in English for specific purpose: A multi-disciplinary approach. Cambridge: Cambridge University Press.

Durga, M. V. S. S. (2018). The need of English language skills for employment Opportunities. Journal for Research Scholars and Professionals of English Language Learning, 7(2), 1-5.

Elyas, T., \& Alghofaili, N. (2019). Native English speakers versus non-native English speakers: The impact of language teachers on EFL learner's English proficiency. English Review Journal of English Education, 7(2). DOI: 10.25134/erjee.v7i2.1773

Erling, E. (2017). Language planning, English language education and development aid in Bangladesh. Current Issues in Language Planning, 18(1):1-19.

DOI:10.1080/14664208.2017.1331496

Gjata, F. (2017). English and its role in the development of tourism in Albania and in the world. ANGLISTICUM. Journal of the Association-Institution for English Language and American Studies (IJLLIS), 6(11), 61-65. https://doi.org/10.5281/zenodo.1079902 
Hashmi, U. M., Rajab, H., \& Sindi, A. E. (2020). Dental students' perceptions of ESP material and its impact on their language proficiency: A case study of a Saudi Arabian university. Arab World English Journal, 10(4), 3-17. DOI: https://dx.doi.org/10.24093/awej/vol10no4.1

Hutchinson, T., \& Waters, A. (1987). English for specific purposes: A learning-centered approach. Cambridge: Cambridge University Press. Ireland, G. V. \& Benthuysen, R. V. (2014). Contemporary issues in EFL education in Myanmar, contemporary issues in EFL education in Myanmar, 151-160. Retrieved from https://www.u-bunkyo.ac.jp/center/library/151-160\%28Gary\%20V.\%20Ireland

Kaewpet, C. (2009). Communication needs of Thai civil engineering students. English for specific purposes, 28(4), 266-278. DOI: 10.1016/j.esp.2009.05.002

Lai, C. L., \& Hwang, G. J. (2014). Effects of mobile learning time on students' conception of collaboration, communication, complex problem-solving, meta-cognitive awareness and creativity. International Journal of Mobile Learning and Organisation, 8(3/4), 276. DOI: $10.1504 /$ IJMLO.2014.067029

Mauranen, A. (2006). Signaling and preventing misunderstanding in English as lingua franca communication. International Journal of the Sociology of Language, (177), 123-150. DOI: $10.1515 /$ IJSL.2006.008

Miina, O. (2014). Effects of using English in business communication in Japanese-based multinational corporations. Master's Thesis. University of Oulu.

MOE (2013). Education System in Myanmar: Self-Evaluation and Future Plans, http://www.myanmar-education.edu.mm/dhel/education-system-inmyanmar/education- law/, Retrieved 17 July 2018.

Neeley, T. (2012). Global Business Speaks English. [online] Harvard Business Review. Available at: https://hbr.org/2012/05/global-business-speaks-english [Accessed 15 Jul. 2017].

Oktarin, R., Syahrial, S., \& Harahap, A. (2019). Needs analysis of ESP for tourism study program at Senior Vocational School, Kota Bengkulu. Journal of English Education and Teaching, 3(1), 14-28. https://doi.org/10.33369/jeet.3.1.14-28

Pandey, M., \& Pandey, P. (2014). Better English for better employment opportunities. International journal of multidisciplinary approach and studies, 1(4), 93-100.

Pattanapichet, F., \& Chinokul, S. (2011). Competencies needed in oral communication in English among Thai undergraduate public relations students: A substantial gap between expectations and reality. RELC Journal, 42(2), 187-202. https://doi.org/10.1177/0033688211401253

Robinson, P. C. (1991). ESP Today: Practitioner's Guide. New York: Prentice Hall

Sadiku, L. M. (2015). The importance of four skills reading, speaking, writing, listening in a lesson hour. European Journal of Language and Literature, 1(1), 29-31. DOI: http://dx.doi.org/10.26417/ejls.v1i1.p29-31

Saleh, N. S., \& Murtaza, S. F. (2018). English Language use in Malaysian government and private civil engineering workplaces. International Journal of Education and Literacy Studies, 6(3), 84-91.

Schachter, A. (2013). Sometimes it's not what you say or how you say it... it's the language you pick, Arts, Culture \& Media. Retrieved from https://www.pri.org/stories/2013-0926/sometimes-its-not-what-you-say-or-how-you-say-it-its-language-you-pick 
Soe, T. (2015). A Study of contemporary trends and challenges of English language teaching in Myanmar. International Conference on Burma/Myanmar Studies

Takahashi, K. (2014). English in Myanmar. Retrieved from language on the move website: http://www.languageonthemove.com/category/language-globalization/page/2

Wong, S. (2005). English in Myanmar. RELC, 36A, 93-104. DOI: 10.1177/0033688205053485

Ting, S. H., Marzuki, E., Chuah, K. M., Misieng, J., \& Jerome, C. (2017). Employers' views on importance of English proficiency and communication skill for employability in Malaysia. Indonesian Journal of Applied Linguistics, 7(2), 315-327. DOI: 10.17509/ijal.v7i2.8132

UNICEF Myanmar (March 2013). Improving learning environment for primary school children in Myanmar, http://www.unicef.org/myanmar/media_20729.html, Retrieved 15 July 2019.

UNESCO (2010). UIS statistics in brief: Education profile - Myanmar. Paris: UNESCO institute of Statistics. 5

Vine, K. (2010). Quantitative study of child friendly school implementation in Myanmar. UNICEF: Myanmar. 